\title{
Calibrating HRM and Marketing Practices for Job Satisfaction: The Role of Internal Marketing and Internal Market Orientation
}

\author{
Faryal Rehman ${ }^{1}$, Muhammad Nouman ${ }^{2}$
}

\begin{abstract}
Services sector is characterized by greater interactions among employees and the customers of an organizations. Satisfied employees or internal customers can lead to satisfied external customers; thus suggesting the need for calibrating HRM with marketing practices. The higher education sector in Pakistan is no different where increasing competition for quality students and rankings is putting strain on the organizations and their employees, especially the faculty. Internal marketing (IM) that attunes HRM approaches with a marketing paradigm is emerging as a new management tool. It focuses on addressing internal customers' needs in order to improve organizational performance vis-à-vis external customers. Literature suggests that IM can be achieved through internal market orientation (IMO). Also, the more an organization focuses on IM, the more its employees will be satisfied with their jobs. This paper studies the impact of IMO on IM, the impact of IM and IMO on job satisfaction and the mediating role of IM between IMO and job satisfaction within the context of the higher education sector. For this purpose a quantitative study on 10 different universities and institutes having a management department was conducted. Faculty members and representatives of senior management were targeted for data collection. Results show positive relationships between IMO, IM and job satisfaction; thus extending the theory to the higher education context. From the results it can be concluded that IM is influenced by IMO and is as important for service organizations as external marketing. It further strengthens the notion that without satisfied internal customers in the form of faculty, higher education institutions may struggle to improve their quality, rankings, and financial performance.
\end{abstract}

Keywords: internal marketing, internal market orientation, job satisfaction, internal customers

\section{Introduction}

The concept of internal marketing (IM) was introduced during the 1970's. Though the topic has been studied since the last 30 years, confusion remains about

1 Institute of Management Sciences, Peshawar, Pakistan

2 Assistant Professor at the Institute of Management Sciences, Peshawar, Pakistan. He is the corresponding author. Contact details: email: muhammad.nouman@imsciences.edu.pk1-A, E/5, Phase 7, Hayatabad Peshawar, Pakistan Phone: +92 91 5861024-25, Ext. 201 
the proper definition of IM, its different components and its importance within the context of an organization's relationship with its employees or internal customers (Tsai, 2014; Dahl \& Peltier, 2014; Rafiq \& Ahmed, 2000). In order to implement IM, it is important for organizations to have some level of internal market orientation (IMO). Studies show that the employees' job satisfaction is directly influenced by the adoption of IMO and IM, where IMO affects job satisfaction more as compared to IM (Gounaris, 2008). Job satisfaction is an important need of organizations as it helps increase satisfaction level of internal as well as external customers. It suggests the need for integrating marketing and human resource management practices (Saad, Hassan, \& Shya, 2015; Rafiq \& Ahmed, 1993). According to Schwepker and Good (2004), job satisfaction is the main focus of internal marketing efforts.

Berry, Hensel, and Burke (1976) introduced the concept of IM by suggesting that employees are internal customers of a business and their jobs are the products that will satisfy their needs. They considered it a source of quality service. According to Naude, Desai, and Murphy (2003), components of IM include socialization, participation in decision making, employee commitment, and accuracy and openness of communication. Whereas Bansal, Mendelson, and Sharma (2001) argue that IM consists of trainings focused on the tasks to be carried out by employees, employee empowerment, flow of information, and reward system of the employees. Ahmad and Rafiq (2000) defined IM as a marketing-like approach used to handle resistance faced within organizations, motivate and produce customer oriented employees that result in satisfied external customers. However, limited work has been carried out to help us understand the relationship among IM, IMO, and job satisfaction.

A detailed review of literature carried out for this paper and presented in the ensuing section suggests that IMO acts as an antecedent to IM (Gounaris, 2008) and that IM has a positive effect on job satisfaction (Ahmad, Rafiq, \& Saad, 2003). However, these issues have been investigated in limited scenarios and contexts whereby there is a need for finding out if the theory and relationships remain generalizable to other contexts with new datasets. Consequently, three research objectives are established for this paper as below:

a. To study the impact of IM and IMO on job satisfaction

b. To study the impact of IMO on IM

c. To study the mediating role of IM between IMO and job satisfaction

For this paper, educational institutes of Peshawar are targeted because of limited work done in this sector. Peshawar, being the capital of the Khyber Pakhtunkhwa has been witness to conflicts especially over the last 10 years. Organizations have tradition- 
ally struggled to attract and retain good human resource as employees have preferred to leave the region in search for better and more secure employment opportunities especially during the last 10 years (SDPI, 2014). As a result, it has become important for organizations working in the Peshawar region, including the higher education sector, to understand and cater the needs of employees working during difficult times. IM can play a vital role and help motivate and retain experienced human resource (Rafiq \& Ahmed, 2000; Berry et al., 1976). For this study, data is collected from 10 higher education institutes of Peshawar. Two questionnaires are designed in order to collect data from faculty as well as the higher management of these institutes.

\section{Literature Review}

\subsection{Service Marketing Triangle}

The idea of IM comes from Kotler and Armstrong's (1991) proposed services marketing triangle that showed the relationship between an organization, its employees, and customers. In this triangle, the three marketing activities are considered important for the success of an organization. These three activities are:

a. External marketing: it occurs between a company and customers (Gronroos, Upah, \& Zeithaml, 1985)

b. Interactive marketing: it occurs between employee and customer (Bitner, 1990)

c. Internal marketing: it occurs between a company and the employees (Berry, 1976)

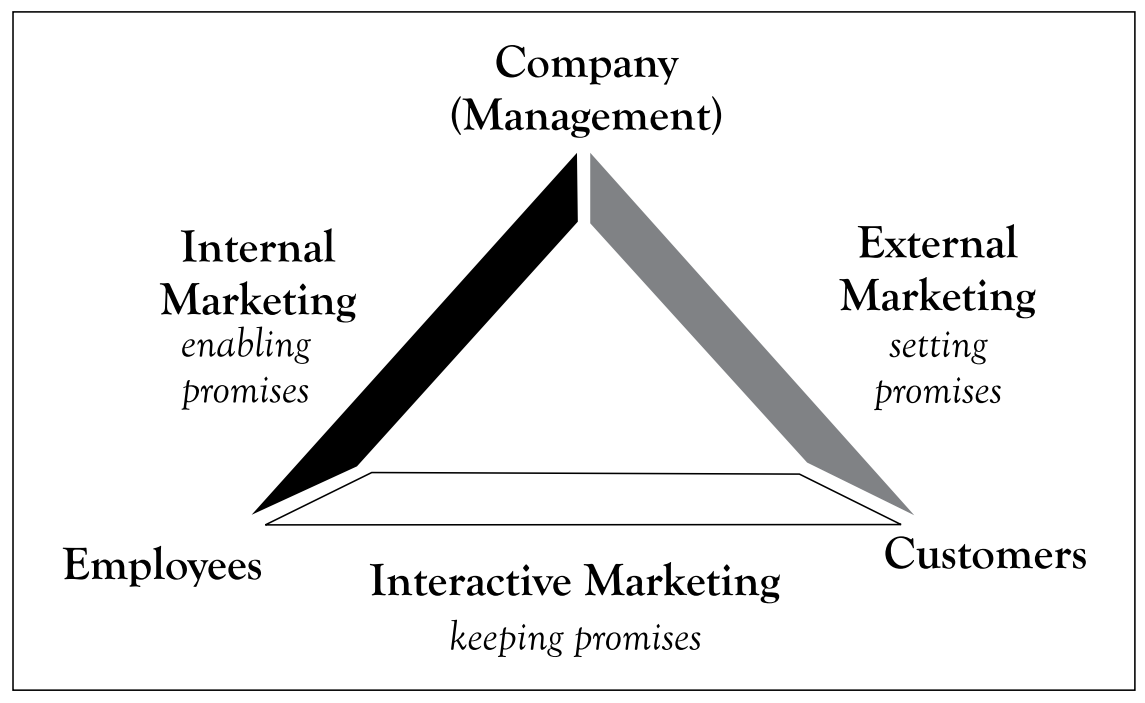

Figure 1: Service Marketing Triangle - adopted from Kotler and Armstrong (1991) 
The main idea behind this triangle is that an organization takes care of its employees which influences their interaction with customers who are attracted by the external marketing of that organization. This justifies the need to study and practice internal marketing and internal market orientation.

\subsection{Internal Marketing (IM)}

Traditionally, research work on IM has mainly focused on employee motivation and satisfaction because the main objective had been to improve a firm's quality of services. The basic logic behind this contention was that in order to have satisfied external customers, organizations should have satisfied internal customers (Tsai, 2014). Later, attention shifted to the thought that employees should be customer oriented because it produced marketing opportunities for organizations. The concept of IM then switched from having satisfied internal customers to having customer oriented employees. Later on, IM was considered as a tool for change management (Dahl \& Peltier, 2014; Rafiq \& Ahmed, 2000). For better communication and for reducing conflicts among departments, IM was considered as a tool for improvement through implementation of new and integrated strategies. This shows that IM is not limited to satisfaction and motivation of employees only, rather it has a wider scope. For example, it can even help to lower the resistance to change within an organization. Ahmad and Rafiq (2000) define IM as "a planned effort using a marketing-like approach to overcome organizational resistance to change.....in order to deliver customer satisfaction through a process of creating motivated and customer orientated employees" (p. 85).

Foreman and Money (1995) stated that IM is a behavioural tool and the objectives of internal marketing change with the audience, whether it is targeted towards a group of internal customers, the whole organization, or a single department. It can be practiced through proper communication, motivation, reward and participative management.

Development of relationships between an organization and its employees is the main aim of internal marketing. Objectives of internal marketing proposed by Ahmed, Rafiq, and Saad (2003) include increasing employee efforts for organization, the commitment of employees, the involvement of employees, motivation level, and job satisfaction. Marketing and Human Resource Management (HRM) together provide better understanding of the philosophy of considering employees as the internal customers of organization through psychological theory (Dunne \& Barnes, 2000). IM mainly aims at enhancing the abilities of capable employees, which in turn shows a connection between IM and human resources (HR). IM's focus is on considering employees of an organization as their internal customers and their work as the product which is a source of satisfaction for employees, which ultimately leads to the achieve- 
ment of organizational goals (Preston \& Steel, 2002). Mishra (2010) considered IM as a source of improving services through motivating employees and improving customer consciousness of employees and identified it as a source of motivation for employees in service industry. Managers must prefer their employee engagement because this leads to positive IM (Das, 2003). Bansal et al. (2001) argue that components of IM are key elements of HRM, which include job security, trainings, reward system, flow of information, employee empowerment etc. However according to Gounaris (2008), the only thing that differentiates internal marketing from HR is that in former, final consumers are kept in mind; while in HRM, only employees' needs are the focus.

In today's competitive environment where organizations face many management challenges, one possible way of marketing, especially in the services industry, is through the effective deployment of employees. According to Cooper and Cronin (2000) employees are the sources of attracting customers within services industry. Therefore, IM should be adopted by organizations for the purpose of better management of human resource in order to provide better services to external customers. IM helps promote a culture where strategies are developed to increase employee satisfaction and commitment to obtain the objectives of organization (Bowen \& Ford, 2002; Kelemen \& Papasolomou, 2004; Gounaris, 2008; Robert-Lombard, 2010). All this work suggests that the concept of internal marketing cannot be ignored. Rather, it should be in place prior to the implementation of conventional external marketing practices.

\subsection{Employees as Internal Customers}

Employees of an organization are considered as the internal customers of that organization (Voss, Calantone, \& Keller, 2005). Drake, Gulman, and Roberts (2005) asserted that by engaging in a carefully planned internal marketing effort, a corporation can convert employees into company "fanatics" who will generate financial rewards. According to Shahzad and Naeem (2013), IM is a strategy where employees are treated as internal customers, and where needs of internal customers are fulfilled in order to make them work in a much better way for the success of the organization.

Robert-Lombard (2010) in his work on the importance of maintaining a good relationship with employees as being the internal customers of the organization state that communication between managers and employees needs to be improved, for this will increase respect and trust between them. Ahmad and Rafiq (2003) argue that internal customers are like external customers and they also want their needs to be addressed. 


\subsection{IM and Job Satisfaction}

Ahmed et al. (2003) studied the effect of IM on employee job satisfaction and found a positive relation between the two. The same results were found by Hwang and Chi (2005) in their research on international hotels of Taiwan. A study done to investigate the effect of IM on job satisfaction level in hospitals also supported the positive relation between the two variables (Chang \& Chang, 2007; Iliopoulus \& Priporas, 2011; Ahmad \& Al Borie, 2012). Gounaris (2008) stated that job satisfaction of employees is the result of IM components like empowerment, participative decision making, and informal communication. In a study on retail shops of India, Nitalla and Kameswari (2009) concluded that IM has a strong impact on job satisfaction of employees. Al-Hawary, Al-Qudah, Abutayeh, Abutayeh, \& Al-Zyadat (2013) in their study on banks of Jordan also concluded that IM and job satisfaction were positively correlated.

According to Shahzad and Naeem (2013), there is a significant relationship between IM and job satisfaction of employees, confirming works of Paulin, Ferguson, and Bergeron (2006), Ahmad et al. (2001), Rafiq \& Ahmed (2000), and Conduit \& Mavondo (2001). Previous researches state that IM increases job satisfaction which further improves the performance of organizations (Nebeker et al., 2001).

Gounaris (2008) in his work stated that employees' job satisfaction is directly influenced by the adoption of IMO and IM, where IMO effects job satisfaction more as compared to IM. This shows the importance of job satisfaction of internal customers and for doing this, adoption of internal marketing becomes important (Schwepker \& Good, 2004).

Though IM had been studied in different service sectors, the authors did not find any research within the education sector. A study on understanding IM within educational institutes will help deliver efficient services to the students. This will help management implement IM and ultimately benefit all stakeholders, especially students. From this discussion the following hypothesis is derived:

$H_{1}$ : IM has a significant impact on job satisfaction.

\subsection{Internal Market Orientation (IMO)}

Internal Market Orientation (IMO) can also be called an employee orientation in which market orientation is adopted within internal market. In the services industry, employees are considered to act as barriers for external market. However, this problem can be solved by introducing the concept of IM. Culture of an organization affects adoption of IMO where its adoption acts as an antecedent to IM within organizations. 
According to Gounaris (2008), "IMO is a company philosophy based on viewing organizations' jobs as internal products and employees as internal customers of these" (p. 403). In other words, IMO can be conceptualized as the adoption of marketing like approach towards the human resource of an organization. Lings (2004) developed a model to show relationship between internal market orientation and external market orientation.

a) Internal Market Intelligence Orientation: This includes determination of employees with different needs and wants and the formation of strategies for benefiting them.

b) Internal Intelligence Dissemination: This includes communication between managers and employees and among managers of different departments.

c) Response to Internal Intelligence: Responsiveness refers to the formation of such jobs which are in line with the needs of employees, designing a reward system according to those needs, realization of employees' importance to the management, and trainings which are delivered to employees in order to improve their performance.

Internal Marketing is a cultural framework used to produce service competence through improved internal communications (Ahmad \& Rafiq, 2003). They also argue that IM positively affect the job satisfaction of employees. Such studies suggest that organizations which are market oriented should be practicing IM concept, where in reality organizations practicing IM concept are less (Rafiq \& Ahmed, 2000).

\subsection{IMO as an Antecedent of IM}

IMO is important for service industry where employees directly influence the customers of an organization. Therefore, it has become a need for service companies to adopt such market orientation. IMO is similar to market orientation where the latter influences external marketing practices in the same way as IMO does.

IMO adoption helps in the effective implementation of IM strategies which then positively influence the competitive position of an organization in the external market (Ahmad et al., 2003). The more an organization adopts IMO strategy, the more will be the use of participative management and the more an organization will be committed to design its internal marketing (IM) program (Gounaris, 2008).

Gounaris (2008) suggested that IMO is a philosophy while IM is a tool for implementing it. The adoption of IMO determines the degree to which an organization implements IM strategies. IMO complements the market orientation of an organiza- 
tion and affects its performance directly or indirectly.

Gounaris (2008) proposed that IMO is an antecedent to IM practice, just like market orientation is an antecedent to marketing practices of the company. It can be concluded that the more an organization is employee oriented, the more it will adopt IM practices. From the literature it can be deduced that there is a lack of quantitative empirical evidence on the relationship between IMO and IM and no evidence of such relationship within education sector exists. This leads to the formation of second hypothesis of the study:

$\mathrm{H}_{2}: \mathrm{IMO}$ has a significant impact on IM.

\subsection{IMO and Job Satisfaction}

Internal market orientation comes under the broad concept of relationship marketing in which an organization has to take care of the needs and wants of external as well as internal customers who are providing the services. Therefore, adopting IMO concept does not mean that the organization aims to produce job satisfaction only. It is these misconceptions which make it hard to differentiate between HR practices and IM practices. The main aim of IM is to achieve the overall market objectives of an organization which are financial as well as the non-financial in nature. Thus it can be concluded that organizations adopting IMO concept have an extrospection perspective whereby IMO can be a prerequisite for IM practices.

As the organization's market orientation positively affects the performance in external market (Slater \& Narver, 2000), similarly the adoption of IMO leads to higher level of job satisfaction of their internal customers (Gounaris, 2006). Carlos and Rodrigues (2012) in their study regarding impact of IMO on job satisfaction in higher education sector concluded that IMO directly effects job satisfaction of faculty members. Similarly, Gounaris (2008) in his study concluded that employees' job satisfaction is directly influenced by the adoption of IMO and IM, where the former affects job satisfaction more as compared to the latter. Again, there is a lack of evidence regarding the effect of IMO on job satisfaction within education sector of Peshawar. This leads to the formation of third hypothesis of the study:

$\mathrm{H}_{3}$ : IMO has a significant impact on job satisfaction.

\subsection{Mediating Role of IM}

Lings and Greenley (2009) studied the relationship between IM and internal market orientation and its ultimate impact on organization's performance. They operationalized IM as a tool for IMO behaviour. Results showed a significant relationship 
between IMO, motivation of employees, and success of external marketing. In order to implement IM in a better way it is important to have cooperation between HR and marketing functions and avoid conflicts (Ahmed et al., 2003). Gounaris (2008) and Ahmed et al. (2003) in their landmark works show that organizational culture affects the adoption of internal market orientation, where IMO is an important element in the implementation of IM within an organization. The degree of job satisfaction is dependent upon the degree to which IMO concept has been adopted and IM is practiced. Gounaris (2008) goes on to suggest that IMO is a concept whereas IM is a tool for practicing it, which ultimately leads to the job satisfaction of employees. IM and IMO both influence the job satisfaction of employees. Unless an organization adopts market orientation within internal environment, it cannot enjoy marketing as a philosophy and at the same time be fully customer oriented (Lings, 2004). IMO falls under the broad category of marketing philosophy and complements market orientation. IMO focuses on the needs and wants of internal customers who can be satisfied through an IM program (Gounaris, 2008) which ultimately affects the job satisfaction of employees. Though Gounaris proposed this relationship by conducting interviews, there is a lack of quantitative empirical evidence on such relationship. Therefore, a need is arises to investigate the mediating role of IM between IMO and job satisfaction. This leads to the formation of fourth hypothesis of the study:

$\mathrm{H}_{4}: \mathrm{IM}$ acts as a mediator between IMO and job satisfaction.

The study focuses on finding relationship among mentioned variables, i.e. internal market orientation, internal marketing and job satisfaction. The conceptual framework is as follows:

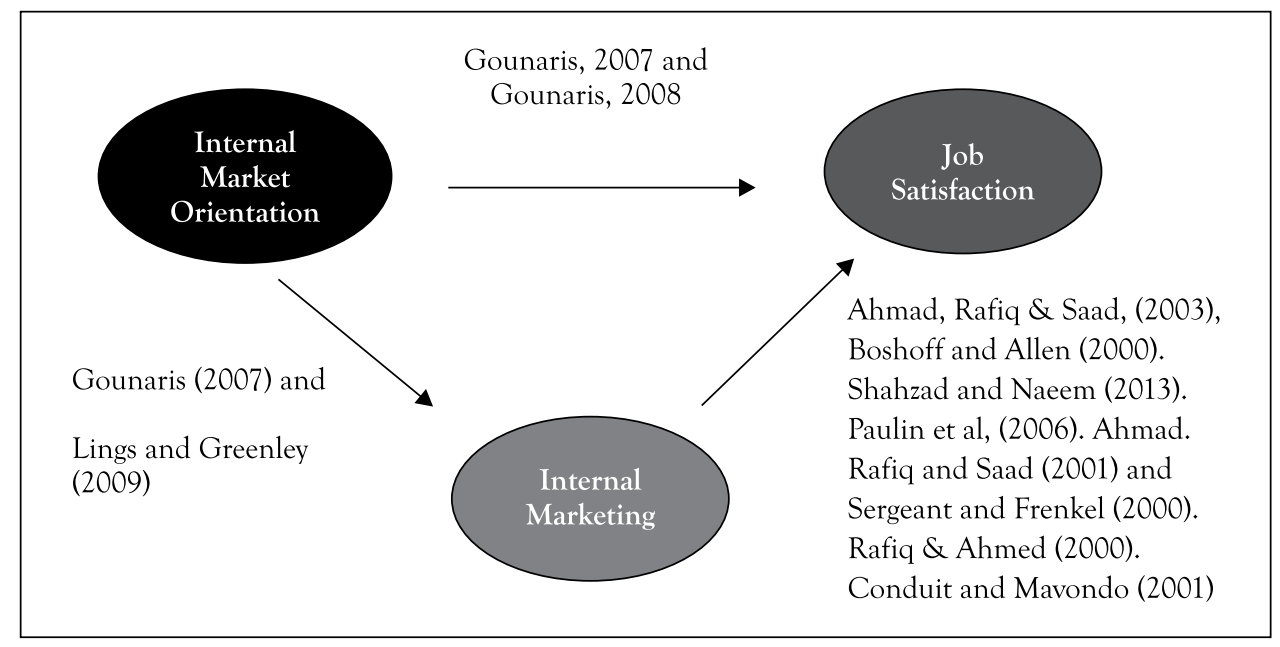

Figure 2: Schematic Representation of the Model 
The framework presented shows a direct effect of IMO on job satisfaction and the mediating role of IM between IMO and job satisfaction. The idea is mainly generated from the works of Gounaris (2008) where the researcher considered internal market orientation important for IM which ultimately affects the job satisfaction of employees. Literature also shows a direct effect of IM on job satisfaction. Most of the work done on IM is in the banking sector while we find a lack of studies in the education sector. According to the literature, IM is important for all service providing organizations where employees are in direct contact with the customers. In order to satisfy the needs of external customers, it becomes important to satisfy the needs of internal customers first where IM acts as a tool for satisfying employees' needs.

\section{Methodology and Methods}

Survey strategy is used for the study with questionnaire as data collection tool. The choice of strategy is relevant as it helps in collecting quantitative data that can be analysed statistically. Survey is not only economical but also helps determine relationships among variables (Saunders, Lewis, \& Thornhill, 2006). Moreover, large amount of data on a wide range of factors like behaviours, attitudes, opinions etc. of participants can be collected within a short period of time using this strategy.

\subsection{Respondents}

Respondents chosen for the study were faculty members of management schools and at least one member from each university who was directly involved in administrative and HR-related functions of the institution. Two stratums were selected to study IM from the management as well as faculty's point of view. While IM is considered essential for all service-oriented organizations, higher education institutes are peculiar in the sense that they possess highly qualified staff. Good quality of staff determines the success and good ranking of a university. Therefore, paying due attention to issues that can improve job satisfaction can directly influence the overall performance of a university. Job satisfaction is of great importance in education sector because the clients are students who are the building blocks for a prosperous society. Literature suggests that IM and IMO both help in attaining job satisfaction of employees (see Gounaris, 2008)

Faculty members are selected because they provide services to the ultimate customers, i.e. students. Their satisfaction with their jobs is vital for providing quality services. Members from administrative side are selected because they are involved in strategic decision making and have a broader perspective about the overall direction as well as HR-related issues within the institutes. Their decisions can also have a direct influence on the incentives and rewards employees are offered. Moreover, their insights 
can offer a clear understanding regarding how the university administration decides for its employees and what steps it takes that can influence faculty's job satisfaction. It is important to point out that the university management and faculty were asked similar set of questions using the questionnaire in order to assess what each group had to say about the level of IM and IMO practiced within an organization and at the same time check the job satisfaction level of employees because of the presence of IM and IMO within these institutes.

\subsection{Calculating the Means}

Means of IMO and IM for higher management and faculty are calculated in order to check whether IMO is practiced within these universities or not. The mean values for higher management show that IMO and IM are "somewhat" practiced within their respective universities as evident from Table 1.

A 7 point Likert scale, as given in the original paper (attached in appendix), is used for questionnaire items where 1 represented "Strongly Agree" and 7 represented

Table 1: IMO and IM means (For Higher Management)

\begin{tabular}{|c|c|}
\hline IMO & 3.4 \\
\hline IM & 3.4 \\
\hline
\end{tabular}

"Strongly Disagree". Since the values of IMO and IM are the same i.e. 3.4, and are also below 4 which is the midpoint, it suggests that according to the management the universities are somewhat employee-oriented. This leads us to conclude that they practice IMO using IM tools like providing better jobs, rewards, and focus on communication etc.

However, the mean values of IMO and IM derived from the responses of the faculty are somewhat different than the management. This shows a difference of opinion regarding the practice of IMO and IM tools. The values calculated for faculty are provided in Table 2. These values show that the faculty disagrees with the management's opinion. One possible reason for this difference could be assessed from the fact that some, if not all, representatives from university management would avoid portraying

Table 2: IMO and IM means (For Faculty)

\begin{tabular}{|c|c|}
\hline IMO & 4.7 \\
\hline IM & 4.1 \\
\hline
\end{tabular}


a bad image of their organization. This is precisely why faculty members were selected for data collection in order to know about the actual situation of IMO within these universities. It is a common observation that most employers believes they are doing a lot for their employees whereas employees may at times disagree with this assessment.

\subsection{Data Collection Procedures}

Data collection for this study was done in two phases. Initially, the Higher Education Commission (HEC) Pakistan's website was studied to find out all the public and private sector universities with a management school or department which are located in Peshawar. A total of 5 universities were identified as private (Abasyn University, CECOS University, City University, Iqra National University, and Sarhad University) while 5 were operating in the public sector (Frontier Women University, Institute of Management Sciences, Islamia College University, Agriculture University, and Institute of Management Studies). Other universities were ignored because the scope of the study was limited to management schools only along with size concerns of the institutes. In the next step websites of all universities were visited to prepare a list of management faculty along with their email addresses. The total population for the study was found to be 224. Initially, email was used as a source of medium for sending questionnaires to all faculty members. However, due to a low response rate from this method, an online survey was designed and sent as a reminder email to all members. Response for online survey was higher. It also emerged that all universities did not have a list of email addresses of their members. Consequently, data in such cases was collected through self-administered questionnaires.

\subsection{Developing the Instrument}

For measuring IMO, the scale developed by Lings and Greenley (2005) is used. Five dimensions used for the measurement are formal written information generation, formal face to face information generation, informal information generation, communication and dissemination of information, and response to internal market information. The total number of items is 16 . This scale has also been used by Tortosa, Moliner, and Sanchez (2009), Tag-Eldeen and El-Said (2011), and Amangala and Amangala (2013) for their studies on IMO within different sectors. IM is measured using a scale developed by Money and Foreman (1995). It is a 15 items questionnaire which measures IM on three different dimensions including vision, development, and reward. This scale has also been used by Bellaouaied and Gam (2011) and Iliopoulos and Priporas (2011) in their studies on internal marketing. According to Foreman and Money (1995), reliability of the instrument was 0.92 showing desirable levels of internal consistency. For measuring job satisfaction, Spector's (1985) scale is used which consists of 9 dimensions. The scale was primarily developed to determine 
employees' job satisfaction within service industries, non-profit organizations, and public organizations. Five dimensions of the scale were added to the questionnaire, which were supervisor satisfaction, co-worker satisfaction, rewards satisfaction, work itself satisfaction, and communication satisfaction. The total number of items was 20 . These items are selected because they are related to IM. It has been used by Al-Hawary et al. (2013) in determining relationship between IM and job satisfaction.

\subsection{Sampling Technique}

In order to target specific kind of educational institutions, purposive sampling was done in the first step for selecting specific universities. The total number of private sector universities on HEC website was 6 and the total number of public sector universities was 7 . Out of these 13 universities only those universities were selected which offered business education, leaving only 10 universities for the study. In the next stage, sampling was carried out for the whole population of 224 which included two groups, i.e. faculty and higher management. These two steps made it a multi-stage sampling.

In stage one, the whole number of private and public sector universities of Peshawar on HEC list were noted. Out of 13, 7 were public sector universities while 6 were private sector universities. All those universities were selected which offered business education, making it a purposive sampling. Purposive sampling is undertaken when a certain criteria is set for the selection of sample units (Saunders et al., 2006). By setting this criterion the number of universities left was 10 . After the selection of universities, faculty members and higher management were targeted.

Initially, only faculty members were targeted but because of the change in opinion between higher management and faculty members as far as the adoption of IMO within organizations is concerned, two strata were formed. Stratification is a probability sampling technique in which groups are formed and each group has some common characteristics. For the study there were two different groups with different characteristics due to which stratification technique was adopted. Out of the two strata, one stratum represented the higher management and the other stratum represented faculty members. The questionnaires were sent to the whole list of members provided on the website of each university. Total number of faculty members, which formed one stratum, was 224 and the sample size was 145, calculated at 95\% confidence interval and $5 \%$ margin of error with the help of online sample calculator. The total number of higher management members was 61 and the sample was 10, one representative from each university. Thus the total sample size at the end came up to be $155(145+10)$. 


\subsection{Addressing Quality Issues in this Research}

For dealing with quality issues, reliability of both the questionnaires was checked using Cronbach's Alpha. The more its value is close to 1 , the better it is. The minimum acceptable value is 0.6 (Hair Jr, Anderson, Tatham, \& Black 1998). The reliability values for faculty and employer questionnaires are as follows:

As evident from Table 3, all the values are greater than 0.6 , showing that the questionnaires used were reliable and good tools for data collection.

Table 3: Cronbach's alpha values for questionnaires

\begin{tabular}{|c|c|}
\hline \multicolumn{2}{|c|}{ Faculty Tool Cronbach Alpha's Value } \\
\hline IMO & 0.898 \\
\hline IM & 0.896 \\
\hline Job Satisfaction & 0.650 \\
\hline \multicolumn{2}{|c|}{ Employer Tool Cronbach Alpha's Value } \\
\hline IMO & 0.898 \\
\hline IM & 0.896 \\
\hline
\end{tabular}

\section{Results and Discussion}

\subsection{Linear Regression}

In order to check the impact of IMO and IM on job satisfaction and to check the mediating role of IM between IMO and job satisfaction, linear regression was run. The details are given below:

\subsubsection{IMO and IM}

IMO is considered to be a vital aspect especially for service sector organizations because service delivery requires direct interaction between the employees and customers of an organization. According to Gounaris (2008), IMO is important for IM practices. In order to study the impact of IMO on IM, linear regression was run. The results of regression model are shown in Table 4:

The value of adjusted $\mathrm{R}$ square is less because Likert scale was used. Significance value of ANOVA is .000 which is less than the level of significance (5\%), showing that the model is good. The coefficient of IMO (0.832) is significant at $5 \%$ level of significance, implying that is has a significant positive impact on IM. 
Table 4: Regression results of IMO and IM

\begin{tabular}{|c|c|c|}
\hline \multicolumn{3}{|c|}{ IMO and IM } \\
\hline Model Summary & Adjusted R Square & .300 \\
\hline ANOVA & Sig & .000 \\
\hline Coefficients & .832 & .000 \\
\hline
\end{tabular}

\subsubsection{IM and Job Satisfaction}

According to Shahzad and Naeem (2013), Paulin et al., (2006), Ahmad et al. (2001), Rafiq and Ahmed (2000), Conduit and Mavondo (2001), and Sergeant and Frenkel (2000) there is a significant relationship between IM and job satisfaction of employees. They worked in different sectors like banks, hotels and retail stores. However, there is a lack of work done in the education sector which, this study attempts to address. Regression model was used to check the impact of IM on job satisfaction. Results are shown in Table 5:

Table 5: Regression results of IM and job satisfaction

\begin{tabular}{|c|c|c|}
\hline \multicolumn{3}{|c|}{ IM and Job Satisfaction } \\
\hline Model Summary & Adjusted R Square & .067 \\
\hline ANOVA & Sig & .001 \\
\hline Coefficients & .431 & .001 \\
\hline
\end{tabular}

Significance value of ANOVA is .001 which is less than the level of significance $(5 \%)$, showing that the model is good. The coefficient of IM (0.431) is significant at $5 \%$ level of significance, implying that is has a significant positive impact on job satisfaction of employees.

\subsubsection{IMO and Job Satisfaction}

A study done by Carlos and Rodrigues (2012) on impact of IMO on job satisfaction in higher education sector concluded that IMO affects the job satisfaction of faculty members directly. At the same time the results showed that IMO is not practiced much in the education sector. Gounaris (2008), in his study on job satisfaction of employees through IMO and IM concluded that IMO affects job satisfaction more as compared to IM. Table 6 shows the regression results of the impact of IMO on job satisfaction. 
Table 6: Regression results of IMO and job satisfaction

\begin{tabular}{|c|c|c|}
\hline \multicolumn{3}{|c|}{ IMO and Job Satisfaction } \\
\hline Model Summary & Adjusted R Square & .196 \\
\hline ANOVA & Sig & .000 \\
\hline Coefficients & .263 & .000 \\
\hline
\end{tabular}

Significance value of ANOVA is .000 which is less than the level of significance (5\%), showing that the model is good. The coefficient of IMO $(0.263)$ is significant at $5 \%$ level of significance, implying that is has a significant positive impact on job satisfaction of employees.

\subsubsection{IM as a mediator between IMO and Job Satisfaction}

According to Gounaris (2008), IMO is a practice and in order to implement it, IM tools are required; this ultimately leads to the job satisfaction of employees. IMO and IM are like external market orientation, i.e. the way market orientation is important to fulfil the needs of customers, in the same way IM and IMO are important for internal customers (Gounaris, 2008). Gounaris conducted interviews from first line employees of hotels, while this study was done to collect data from faculty of management department of different universities. Table 7 shows the results of the mediating role of IM between IMO and job satisfaction:

Table 7: Mediating role of IM between IMO and job satisfaction

\begin{tabular}{|c|c|c|}
\hline \multicolumn{3}{|c|}{ IMO and IM } \\
\hline Model Summary & Adjusted R Square & .300 \\
\hline ANOVA & Sig & .000 \\
\hline Coefficients & .832 & .000 \\
\hline \multicolumn{3}{|c|}{ Sig } \\
\hline IM and Job Satisfaction \\
\hline Model Summary & Adjusted R Square & .067 \\
\hline ANOVA & Sig & .001 \\
\hline Coefficients & .431 & .001 \\
\hline
\end{tabular}


These positive and significant relationships between IMO and IM and between IM and job satisfaction show that IM acts as a mediator between IMO and job satisfaction.

The concept of IM was introduced during the 1970's and focused on considering employees as internal customers of the organization. According to Mishra (2010), the central role of employees is being increasingly realized resulting in the increasing importance of IM practices within organizations. Just like external market orientation positively affects external market (Slater and Naver, 2000), in the same way IMO leads to higher job satisfaction among internal customers (Gounaris, 2006). Employees' job satisfaction is directly influenced by IMO and IM, where IMO effects job satisfaction more (Gounaris, 2008). The more an organization is internally market oriented, the more it will be committed to designing its IM program (Gounaris, 2008). Results obtained from this study agree with previous findings, thus strengthening the theory for higher education sector where both IM and IMO were also found to positively affect job satisfaction and IM acted as a mediator between IMO and job satisfaction.

Literature shows that there is a positive relationship between IM and job satisfaction (Ahmad \& Rafiq, 2000; Shahzad \& Naeem, 2013). While according to Gounaris (2008), IMO is important for the implementation of IM tools. His main idea was that organizations need to be employee oriented, otherwise they would not be able to focus on their internal marketing. Few studies also showed that IMO positively influence job satisfaction of employees (Carlos \& Rodrigues, 2012). Previous studies have been conducted mostly in the banking sector, hotels and retail stores, focusing on IM and job satisfaction; while almost no research has been conducted that incorporated IMO and job satisfaction and tested IM's role as a mediator between IMO and job satisfaction, and that too in the education sector.

Results of the current study show that IM and IMO not only influence the job satisfaction of employees working in other sectors but also of faculty members in education sector. The scope of this study was limited to management departments of universities only. From the results it can be seen that organizations should not only focus on their external marketing but in order to differentiate from other organizations, they need to practice IM as well (Javadein, Rayej, Estiri, \& Ghorbani 2011).

The hypotheses were designed to study the direct effect of IMO and IM on job satisfaction and also to study the mediating role of IM between IMO and job satisfaction. In previous studies, either direct effect of IM on job satisfaction or direct effect of IMO on job satisfaction had been studied independently. This study combined three different variables in education sector in which IM had been studied the least, especially in the case of Pakistan. It can be seen that the results of this study are not different from previous work. It can be concluded that IM and IMO are far 
more important aspects for organizations within the education sector as well. They are not only helpful in increasing job satisfaction of banks and hotel employees but also affect the job satisfaction of management faculty in universities. From the study results it can also be concluded that it is important for organizations to consider their employees as internal customers and fulfil their needs before fulfilling needs of external customers. Importance of employees as means of marketing cannot be ignored, as they are in direct contact with the ultimate users of the services provided by educational institutions.

This study will help educational institutes understand that IMO can help in strengthening coordination between different departments and help solve inter functional conflicts using IM tools. IM includes all those actions of an organization which help in the development, training, and motivation of employees in order to improve service quality provided to customers (Chen, Lin, \& Ho, 2006). In today's world, organizations should not ignore the importance of the IM concept because no one can ignore the role that employees can play in the marketing of an organization. The strong impact of variables on each other tells us that just like market orientation, internal market orientation has now become significant for educational institutes as well. IMO can let employers get close to their employees by listening to their demands and involving them in the development of strategies. IM requires organizations to train and develop their employees, communicate with them, and provide them with rewards so that they can perform well, which is an essential need of every organization. Thus, the importance of IMO and IM and their effect on job satisfaction cannot be ignored in today's competitive world. At the same time, the fact that internal marketing is one of the sources for achieving job satisfaction should not be overlooked.

\section{Conclusion and Recommendations}

Different studies in the banking sector (Shahzad \& Naeem, 2013; Al Hawary et al., 2013), hotels (Gounaris, 2006; Abzari, Ghorbani, \& Madani, 2011), retail stores (Lings, 2000; Lings \& Greenley, 2009) showed positive relationships between IM and job satisfaction, IMO and job satisfaction, and IMO and IM. Thus the results of this study are similar to those determined by previous researchers in different sectors. In different service sectors it has now become important to focus on tools like rewards, supervisor control, job itself, communication etc.--which are IM tools, in order to increase job satisfaction of employees. The results also suggest that organizations practicing IM tools are internally market oriented; or in other words, they are employee-oriented.

The difference in opinion between higher management and faculty members on the implementation of IMO suggests that the management may not be fulfilling all 
perceived needs of their employees. IM promotes a culture in which strategies focus on employee satisfaction for obtaining objectives of the organization (Robert-Lombard, 2010), making it important for organizations to promote such culture for better results. Educational institutes should take into consideration the fulfilment of their employees' needs first which can positively affect the satisfaction level of their clients. According to Drake et al. (2005), proper planning of IM can result in greater financial rewards. One of the most important objectives of every organization is to have profits; educational institutes can get such positive results through their employees. Organizations have to focus on the services and products they provide to achieve satisfaction of both internal and external customers (Lings, 2004). Treating faculty members as internal customers and fulfilling their needs can also make them loyal to their organization. Therefore, it is recommended that the more an organization is employee oriented (IMO), the more positive results it will get. However, the current study is limited to management departments of universities within a particular region. Further work should be carried out on all kinds of departments and organizations to generalize the results, i.e. positive effect of IM and IMO on job satisfaction. Researchers should also study the effect of IM on other factors that might affect the overall performance of an organization. Future researchers can also design tools to study the implementation of IM via other means. Since difference in opinion between faculty members and higher management is observed, it is difficult to fully comprehend the actual situation of IMO and IM within the higher education institutes.

\subsection{Contributions of the Study}

Literature reviewed for this paper predominantly suggested that there is a positive relationship between job satisfaction and IM and IMO and job satisfaction. However, very little work was found on the relationship between IMO and IM and the mediating role of IM between IMO and job satisfaction. This paper confirmed the mediating role of IM between IMO and job satisfaction which was determined by Gounaris (2008) through interviews. It also confirmed the direct effect of IMO on job satisfaction. A lot of work has been done on IM within other sectors like banks and hotels, but almost no attention has been given to the education sector in this regard. This paper extends the theory to education sector; thus contributing to the existing literature. One of the contributions of the study is that it came up with quantitative evidence for the mediating role of IM.

\subsection{Implications for Managers}

Most of the work done in service marketing was mainly focused on the external customers and the quality of services provided to them. Gronroos (1990) suggested that organizations need a culture where employees are ready to respond to unique, 
unforeseen, and awkward situations. Despite the fact that when discussing service marketing, employers mainly focus on the needs of external customers, a service oriented environment and culture to cater the needs of internal customers has also become important. A culture is needed that addresses the needs of employees, even if it requires a change in policy or modification of internal service offerings. An organization's culture would be completely different if it practices "the customer is always right" rule for both internal and external customers. Needs of customers come after the employees' needs because customers' needs will automatically be met if internal customers' needs are met (Rosenbluth \& Peters, 1992).

\section{References}

Abzari, M., Ghorbani, H., \& Madani, F. A. (2011). The effect of internal marketing on organizational commitment from market-orientation viewpoint in hotel industry in Iran. International Journal of Marketing Studies, 3(1), 147.

Ahmad, A. M., \& Al Borie, H. M. (2012). Impact of internal marketing on job satisfaction and organizational commitment: A study of teaching hospitals in Saudi Arabia. Business and Management Research, 1(3), 82.

Ahmed, P. K., \& Rafiq, M. (2003). Internal marketing issues and challenges. European Journal of Marketing, 37(9), 1177-1186.

Ahmed, P. K., Rafiq, M., \& Saad, N. M. (2003). Internal marketing and the mediating role of organizational competencies. European Journal of Marketing, 37(9), 1221-1241.

Al-Hawary, S. I., Al-Qudah, K. A., Abutayeh, P. M., Abutayeh, S. M., \& Al-Zyadat, D. Y. (2013). The impact of internal marketing on employees job satisfaction of commercial banks in Jordan. Interdisciplinary Journal of Contemporary Research in Business, 4(9), 811-826.

Amangala, T., \& Amangala, E. (2013). Effects of internal marketing and its components on organisational level customer orientation: An empirical analysis. European Journal of Business and Management, 5(8), 64-73.

Bansal, H. S., Mendelson, M. B., \& Sharma, B. (2001). The impact of internal marketing activities on external marketing output. Journal of Quality Management, 6(1), 61-76.

Bellaouaied, M., \& Gam, A. (2011). Internal marketing as a new alternative for the service employees' performance: An empirical study, Revue de Communication et de Marketing, 2(2), 139-159.

Berry, L.L., Hensel, J.S., \& Burke, M.C. (1976). Improving retailer capability for effective consumerism response. Journal of Retailing, 52(3), 3-14.

Bitner, M. (1990). Evaluating service encounters: The effects of physical surroundings and employee responses. The Journal of Marketing, 54(2), 69-82. 
Bowen, J., \& Ford, R. C. (2002). Managing service organizations: Does having a "thing" make a difference? Journal of Management, 28(3), 447-469.

Carlos, V. S., \& Rodrigues, R. G. (2012). Internal market orientation in higher education institutions- its inter-relations with other organisational variables. Public Policy and Administration, 11(4), 690-702.

Chang, C. S., \& Chang, H. H. (2007). Effects of internal marketing on nurse job satisfaction and organizational commitment: Example of medical centers in Southern Taiwan. Journal of Nursing Research, 15(4), 265-274.

Chen, C., Lin, Y. H., \& Ho, C. S. (2006). Research on the relationship between internal marketing and medical personnel's turnover intention in the situation of a dangerous outbreak of illness like SARS: A regional hospital for Example. Cheng Chin Medical Journal, 2(4), 28-36.

Conduit, J., \& Mavondo, F. T. (2001). How critical is internal customer orientation to market orientation? Journal of Business Research, 51(1), 11-24.

Cooper, J., \& Cronin, J. (2000). Internal marketing: Competitive strategy for the long-term care industry. Journal of Business Research, 48(3), 177-181.

Das, S. (2003). Vacant or engaged? Employee Benefits, 4(2), 24-28.

Dahl, A., \& Peltier, J. (2014). Internal marketing and employee satisfaction and loyalty: Cross-cultural scale validation in context of U.S. and German nurses. Journal of Consumer Satisfaction, Dissatisfaction E Complaining Behavior, 27, 43-53.

Drake, S. M., Gulman, M. J., \& Roberts, S. M. (2005). Light their fire: Using internal marketing to ignite employee performance and wow your customers. Kaplan Publishing.

Dunne, P. A., \& Barnes, J. G. (2000). Internal marketing: A relationships and value-creation view. In R. Varey \& B. Lewis (Eds.), Internal Marketing: Directions for Management. (pp. 192-220). Routledge, London.

Foreman, S. K., \& Money, A. H. (1995). Internal marketing: Concept, measurement and application. Journal of Marketing Management, 11(8), 755-768.

Gounaris, S. P. (2006). Internal-market orientation and its measurement. Journal of Business Research, 59(4), 432-448.

Gounaris, S. (2008). Antecedents of internal marketing practice: Some preliminary empirical evidence. International Journal of Service Industry Management, 19(3), 400-434.

Gronroos, C., Upah, G. D., \& Zeithaml, V. A. (1985). Services Marketing in a changing environment. American Marketing Association, Chicago, 11, 41-47.

Gronroos, C. (1990). Relationship approach to marketing in service contexts: The marketing and organizational behavior interface. Journal of Business Research, 20(1), 3-11. 
Hair Jr, J. F., Anderson, R. E., Tatham, R. L., \& Black, W. C. (1998). Canonical correlation analysis. Multivariate Data Analysis, 768.

Hwang, I. S., \& Chi, D. J. (2005). Relationships among internal marketing, employee job satisfaction and international hotel performance: An empirical study. International Journal of Management, 22(2), 285-293.

Iliopoulos, E., \& Priporas, C. V. (2011). The effect of internal marketing on job satisfaction in health services: A pilot study in public hospitals in Northern Greece. BMC health services research, 11(1), 261.

Javadein, S. S., Rayej, H., Estiri, M., \& Ghorbani, H. (2011). The role of internal marketing in creation of sustainable competitive advantages. Trends in Applied Sciences Research, 6(4), 364-374.

Kelemen, M., \& Papasolomou, D. I. (2004). Can culture be changed? A study of internal marketing. Service Industry Journal, 24(5), 121-135.

Kotler, P., \& Armstrong, G. (1991). Principles of marketing. Englewood Cliffs, NJ: Prentice Hall.

Lings, I. N. (2004). Internal market orientation: Construct and consequences. Journal of Business Research, 57(4), 405-413.

Lings, I. N. (2000). The impact of internal market orientation on external market orientation and business performance: An empirical study of the UK Retail Market. In Proceedings of ANZMAC 2000 Conference, Visionary Marketing for the 21st Century: Facing the Challenge 697-702

Lings, I. N., \& Greenley, G. E. (2005). Measuring internal market orientation. Journal of Service Research, 7(3), 290-305.

Lings, Ian, \& Greenley, G. (2009). The impact of internal and external market orientations on firm performance. Journal of Strategic Marketing, 17(1), 41-53.

Mishra, S. (2010). Internal marketing-A tool to harness employees' power in service organizations in India. International Journal of Business and Management, 5(1), 185.

Naude, P., Desai, J., \& Murphy, J. (2003). Identifying the determinants of internal marketing orientation. European Journal of Marketing, 37(9), 1205-1220.

Nebeker, D., Busso, L., Werenfels, P.D., Diallo, H., Czekajewski, A. \& Ferdman, B. (2001). Airline station performance as a function of employee satisfaction. Journal of Quality Management, 6(1), 29-45.

Nittala, R. and Kameswari, V. A. (2009). Internal marketing for customer satisfaction in retail sector. AIMS International Journal of Management, 3(3), 207-220.

Preston, J., \& Steel, L. (2002). Internal marketing strategies in LIS: A strategic management perspective. Library Management, 23(6/7), 294-301.

Paulin, M., Ferguson, R. J., \& Bergeron, J. (2006). Service climate and organizational commitment: The importance of customer linkages. Journal of Business Research, 59(8), 906-915. 
Rafiq, M., \& Ahmed, P. K. (1993). The scope of internal marketing: Defining the boundary between marketing and human resource management. Journal of Marketing Management, 9(3), 21-232.

Rafiq, M., \& Ahmed, P. K. (2000). Advances in the internal marketing concept: Definition, synthesis and extension. Journal of Services Marketing, 14(6), 449-462.

Roberts-Lombard, M. (2010). Employees as customers - An internal marketing study of the Avis Car Rental Group in South Africa. African Journal of Business Management, 4(4), 362-372.

Rosenbluth, H., \& Peters, D. (1992). The customer comes second: And other secrets of exceptional service. New York, NY: William Morrow and Company.

Saad, N. M., Hassan, S. H., \& Shya, L. M. (2015). Revisiting the relationship between internal marketing and external marketing: The role of customer orientation. The Journal of Developing Areas, 49(3), $249-262$.

Saunders, M., Lewis, P., \& Thornhill, A. (2006). Research methods for business students (4 $4^{\text {th }}$ ed.). Harlow: Prentice Hall.

Schwepker, C., \& Good, D. J. (2004). Marketing control and sales force customer orientation. Journal of Personal Selling $\mathcal{E}$ Sales Management, 24(3), 167-179.

SDPI (2014). Social protection in Khyber Pakhtunkhwa: A policy brief by Sustainable Development Policy Institute, UNDP Pakistan.

Sergeant, A., \& Frenkel, S. (2000). When do customer contact employees satisfy customers?. Journal of Service Research, 3(1), 18-34.

Shahzad, T., \& Naeem, P. D. (2013). Role of internal marketing in employee engagement leading to job satisfaction of employees in private banks of Pakistan. Journal of Business and Management, 8(2), 62-68.

Slater, S. F., \& Narver, J. C. (2000). The positive effect of a market orientation on business profitability: A balanced replication. Journal of Business Research, 48(1), 69-73.

Spector, P. (1985). Measurement of human service staff satisfaction: Development of the job satisfaction. American Journal of Community Psychology, 13(6), 693-713.

Tag-Eldeen, A., \& El-Said, O. A. (2011): Implementation of internal marketing on a sample of Egyptian five-star hotels. Anatolia, 22(2), 153-167.

Tsai, Y. (2014). Learning organizations, internal marketing, and organizational commitment in hospitals. BMC health services research, 14(152), 2-8

Tortosa, V., Moliner, M. A., \& Sanchez, J. (2009). Internal market orientation and its influence on organizational performance. European Journal of Marketing, 43(11/12), 1435-1456.

Voss, M. D., Calantone, R. J., \& Keller, S. B. (2005). Internal service quality: Determinants of distribution centre performance. International Journal of Physical Distribution and Logistics Management, 
35(3), 161-176.

\section{Appendix: Questionnaire}

\begin{tabular}{|c|c|c|c|c|c|c|}
\hline \multicolumn{7}{|c|}{1 IMO: Internal Market Orientation } \\
\hline \multicolumn{7}{|c|}{ 1.1 Informal Information Generation } \\
\hline \multicolumn{7}{|c|}{ 1.1.1 When at work my employer tries to find out what employees want from the company. } \\
\hline $\begin{array}{l}\square \text { Strongly } \\
\text { Agree }\end{array}$ & $\square$ Agree & $\begin{array}{l}\square \text { Some- } \\
\text { what Agree }\end{array}$ & $\begin{array}{c}\square \text { Neither } \\
\text { Agree nor } \\
\text { Disagree }\end{array}$ & $\begin{array}{c}\square \text { Some- } \\
\text { what } \\
\text { Disagree }\end{array}$ & $\square$ Disagree & $\begin{array}{c}\square \text { Strongly } \\
\text { Disagree }\end{array}$ \\
\hline \multicolumn{7}{|c|}{$\begin{array}{l}\text { 1.1.2 When at work if my employer notices that one of the employees is acting differently to nor- } \\
\text { mal he will try to find out if there is a problem which is causing a change in behavior. }\end{array}$} \\
\hline $\begin{array}{l}\square \text { Strongly } \\
\text { Agree }\end{array}$ & $\square$ Agree & $\begin{array}{l}\square \text { Some- } \\
\text { what Agree }\end{array}$ & $\begin{array}{c}\square \text { Neither } \\
\text { Agree nor } \\
\text { Disagree }\end{array}$ & $\begin{array}{c}\square \text { Some- } \\
\text { what } \\
\text { Disagree }\end{array}$ & $\square$ Disagree & $\begin{array}{l}\square \quad \text { Strong- } \\
\text { ly Disagree }\end{array}$ \\
\hline \multicolumn{7}{|c|}{ 1.1.3 When at work my employer tries to find out employees' real feelings about their jobs. } \\
\hline $\begin{array}{l}\square \text { Strongly } \\
\text { Agree }\end{array}$ & $\square$ Agree & $\begin{array}{l}\square \text { Some- } \\
\text { what Agree }\end{array}$ & $\begin{array}{c}\square \text { Neither } \\
\text { Agree nor } \\
\text { Disagree }\end{array}$ & $\begin{array}{c}\square \text { Some- } \\
\text { what } \\
\text { Disagree }\end{array}$ & $\square$ Disagree & $\begin{array}{c}\square \text { Strongly } \\
\text { Disagree }\end{array}$ \\
\hline \multicolumn{7}{|c|}{ 1.1.4 When at work my employer regularly talks to the staff to find out about their work. } \\
\hline $\begin{array}{l}\square \text { Strongly } \\
\text { Agree }\end{array}$ & $\square$ Agree & $\begin{array}{l}\square \text { Some- } \\
\text { what Agree }\end{array}$ & $\begin{array}{c}\square \text { Neither } \\
\text { Agree nor } \\
\text { Disagree }\end{array}$ & $\begin{array}{c}\square \text { Some- } \\
\text { what } \\
\text { Disagree }\end{array}$ & $\square$ Disagree & $\begin{array}{c}\square \text { Strongly } \\
\text { Disagree }\end{array}$ \\
\hline \multicolumn{7}{|c|}{ 1.2 Formal face-to-face information generation } \\
\hline \multicolumn{7}{|c|}{$\begin{array}{l}\text { 1.2.1 In our organization we have regular staff appraisals in which our employer discuss what } \\
\text { employees want. }\end{array}$} \\
\hline $\begin{array}{l}\square \text { Strongly } \\
\text { Agree }\end{array}$ & $\square$ Agree & $\begin{array}{l}\square \text { Some- } \\
\text { what Agree }\end{array}$ & $\begin{array}{c}\square \text { Neither } \\
\text { Agree nor } \\
\text { Disagree }\end{array}$ & $\begin{array}{c}\square \text { Some- } \\
\text { what } \\
\text { Disagree }\end{array}$ & $\square$ Disagree & $\begin{array}{c}\square \text { Strongly } \\
\text { Disagree }\end{array}$ \\
\hline \multicolumn{7}{|c|}{$\begin{array}{l}\text { 1.2.2 In our organization management meets employees at least once a year to find out what } \\
\text { expectations they have of their jobs for the future. }\end{array}$} \\
\hline $\begin{array}{l}\square \text { Strongly } \\
\text { Agree }\end{array}$ & $\square$ Agree & $\begin{array}{l}\square \text { Some- } \\
\text { what Agree }\end{array}$ & $\begin{array}{c}\square \text { Neither } \\
\text { Agree nor } \\
\text { Disagree }\end{array}$ & $\begin{array}{c}\square \text { Some- } \\
\text { what } \\
\text { Disagree }\end{array}$ & $\square$ Disagree & $\begin{array}{c}\square \text { Strongly } \\
\text { Disagree }\end{array}$ \\
\hline \multicolumn{7}{|c|}{$\begin{array}{l}\text { 1.2.3 In our organization management interact directly with employees to find out how to make } \\
\text { them more satisfied. }\end{array}$} \\
\hline $\begin{array}{l}\square \text { Strongly } \\
\text { Agree }\end{array}$ & $\square$ Agree & $\begin{array}{l}\square \text { Some- } \\
\text { what Agree }\end{array}$ & $\begin{array}{c}\square \text { Neither } \\
\text { Agree nor } \\
\text { Disagree }\end{array}$ & $\begin{array}{c}\square \text { Some- } \\
\text { what } \\
\text { Disagree }\end{array}$ & $\square$ Disagree & $\begin{array}{c}\square \text { Strongly } \\
\text { Disagree }\end{array}$ \\
\hline
\end{tabular}




\begin{tabular}{|c|c|c|c|c|c|c|}
\hline $\begin{array}{l}\square \text { Strongly } \\
\text { Agree }\end{array}$ & $\square$ Agree & $\begin{array}{l}\square \text { Some- } \\
\text { what Agree }\end{array}$ & $\begin{array}{c}\square \text { Neither } \\
\text { Agree nor } \\
\text { Disagree }\end{array}$ & $\begin{array}{c}\square \text { Some- } \\
\text { what } \\
\text { Disagree }\end{array}$ & $\square$ Disagree & $\begin{array}{c}\square \text { Strongly } \\
\text { Disagree }\end{array}$ \\
\hline \multicolumn{7}{|c|}{$\begin{array}{l}\text { 1.3.2 In our organization my employer surveys employees at least once a year to assess the quality } \\
\text { of employment. }\end{array}$} \\
\hline $\begin{array}{l}\square \text { Strongly } \\
\text { Agree }\end{array}$ & $\square$ Agree & $\begin{array}{l}\square \text { Some- } \\
\text { what Agree }\end{array}$ & $\begin{array}{c}\square \text { Neither } \\
\text { Agree nor } \\
\text { Disagree }\end{array}$ & $\begin{array}{c}\square \text { Some- } \\
\text { what } \\
\text { Disagree }\end{array}$ & $\square$ Disagree & $\begin{array}{c}\square \text { Strongly } \\
\text { Disagree }\end{array}$ \\
\hline \multicolumn{7}{|c|}{$\begin{array}{l}\text { 1.3.3 In our organization my employer often talks with or survey people to identify influences on } \\
\text { employees' behavior (e.g. Unions, sales representatives, customers). }\end{array}$} \\
\hline $\begin{array}{l}\square \text { Strongly } \\
\text { Agree }\end{array}$ & $\square$ Agree & $\begin{array}{l}\square \text { Some- } \\
\text { what Agree }\end{array}$ & $\begin{array}{c}\square \text { Neither } \\
\text { Agree nor } \\
\text { Disagree }\end{array}$ & $\begin{array}{c}\square \text { Some- } \\
\text { what } \\
\text { Disagree }\end{array}$ & $\square$ Disagree & $\begin{array}{c}\square \text { Strongly } \\
\text { Disagree }\end{array}$ \\
\hline \multicolumn{7}{|c|}{ 1.4 Information Dissemination } \\
\hline \multicolumn{7}{|c|}{$\begin{array}{l}\text { 1.4.1 In our organization my employer regularly meets with all staff to report about issues relating } \\
\text { to the whole organization. }\end{array}$} \\
\hline $\begin{array}{l}\square \text { Strongly } \\
\text { Agree }\end{array}$ & $\square$ Agree & $\begin{array}{l}\square \text { Some- } \\
\text { what Agree }\end{array}$ & $\begin{array}{c}\square \text { Neither } \\
\text { Agree nor } \\
\text { Disagree }\end{array}$ & $\begin{array}{c}\square \text { Some- } \\
\text { what } \\
\text { Disagree }\end{array}$ & $\square$ Disagree & $\begin{array}{c}\square \text { Strongly } \\
\text { Disagree }\end{array}$ \\
\hline \multicolumn{7}{|c|}{$\begin{array}{l}\text { 1.4.2 In our organization my employer regularly reports back to the staff about issues that affect } \\
\text { their working environment. }\end{array}$} \\
\hline $\begin{array}{l}\square \text { Strongly } \\
\text { Agree }\end{array}$ & $\square$ Agree & $\begin{array}{l}\square \text { Some- } \\
\text { what Agree }\end{array}$ & $\begin{array}{c}\square \text { Neither } \\
\text { Agree nor } \\
\text { Disagree }\end{array}$ & $\begin{array}{c}\square \text { Some- } \\
\text { what } \\
\text { Disagree }\end{array}$ & $\square$ Disagree & $\begin{array}{c}\square \text { Strongly } \\
\text { Disagree }\end{array}$ \\
\hline \multicolumn{7}{|c|}{$\begin{array}{l}\text { 1.4.3 In our organization my employers have regular staff meetings with employees at all levels } \\
\text { attending. }\end{array}$} \\
\hline $\begin{array}{l}\square \text { Strongly } \\
\text { Agree }\end{array}$ & $\square$ Agree & $\begin{array}{c}\square \text { Some- } \\
\text { what Agree }\end{array}$ & $\begin{array}{c}\square \text { Neither } \\
\text { Agree nor } \\
\text { Disagree }\end{array}$ & $\begin{array}{c}\square \text { Some- } \\
\text { what } \\
\text { Disagree }\end{array}$ & $\square$ Disagree & $\square$ Disagree \\
\hline \multicolumn{7}{|c|}{$1.5 \quad$ Response } \\
\hline \multicolumn{7}{|c|}{$\begin{array}{l}\text { 1.5.1 In our organization when our employer finds out that employees are unhappy with the } \\
\text { supervision or management, they take corrective action. }\end{array}$} \\
\hline $\begin{array}{l}\square \text { Strongly } \\
\text { Agree }\end{array}$ & $\square$ Agree & $\begin{array}{c}\square \text { Some- } \\
\text { what Agree }\end{array}$ & $\begin{array}{c}\square \text { Neither } \\
\text { Agree nor } \\
\text { Disagree }\end{array}$ & $\begin{array}{c}\square \text { Some- } \\
\text { what } \\
\text { Disagree }\end{array}$ & $\square$ Disagree & $\square$ Disagree \\
\hline
\end{tabular}




\begin{tabular}{|c|c|c|c|c|c|c|}
\hline $\begin{array}{l}\square \text { Strongly } \\
\text { Agree }\end{array}$ & $\square$ Agree & $\begin{array}{l}\square \text { Some- } \\
\text { what Agree }\end{array}$ & $\begin{array}{c}\square \text { Neither } \\
\text { Agree nor } \\
\text { Disagree }\end{array}$ & $\begin{array}{c}\square \text { Some- } \\
\text { what } \\
\text { Disagree }\end{array}$ & $\square$ Disagree & $\square$ Disagree \\
\hline \multicolumn{7}{|c|}{$\begin{array}{l}\text { 1.5.3 In our organization our employer makes changes to what they do when employee feedback } \\
\text { indicates that we are dissatisfied with the status quo. }\end{array}$} \\
\hline $\begin{array}{l}\square \text { Strongly } \\
\text { Agree }\end{array}$ & $\square$ Agree & $\begin{array}{l}\square \text { Some- } \\
\text { what Agree }\end{array}$ & $\begin{array}{c}\square \text { Neither } \\
\text { Agree nor } \\
\text { Disagree }\end{array}$ & $\begin{array}{c}\square \text { Some- } \\
\text { what } \\
\text { Disagree }\end{array}$ & $\square$ Disagree & $\square$ Disagree \\
\hline \multicolumn{7}{|c|}{2 Internal Marketing } \\
\hline \multicolumn{7}{|c|}{ 2.1.1 Our organization offers employees a vision that they can believe in. } \\
\hline $\begin{array}{l}\square \text { Strongly } \\
\text { Agree }\end{array}$ & $\square$ Agree & $\begin{array}{l}\square \text { Some- } \\
\text { what Agree }\end{array}$ & $\begin{array}{c}\square \text { Neither } \\
\text { Agree nor } \\
\text { Disagree }\end{array}$ & $\begin{array}{c}\square \text { Some- } \\
\text { what } \\
\text { Disagree }\end{array}$ & $\square$ Disagree & $\square$ Disagree \\
\hline $\begin{array}{l}\square \text { Strongly } \\
\text { Agree }\end{array}$ & $\square$ Agree & $\begin{array}{l}\square \text { Some- } \\
\text { what Agree }\end{array}$ & $\begin{array}{l}\square \text { Neither } \\
\text { Agree nor } \\
\text { Disagree }\end{array}$ & $\begin{array}{c}\square \text { Some- } \\
\text { what } \\
\text { Disagree }\end{array}$ & $\square$ Disagree & $\square$ Disagree \\
\hline $\begin{array}{l}\square \text { Strongly } \\
\text { Agree }\end{array}$ & $\square$ Agree & $\begin{array}{l}\square \text { Some- } \\
\text { what Agree }\end{array}$ & $\begin{array}{c}\square \text { Neither } \\
\text { Agree nor } \\
\text { Disagree }\end{array}$ & $\begin{array}{c}\square \text { Some- } \\
\text { what } \\
\text { Disagree }\end{array}$ & $\square$ Disagree & $\square$ Disagree \\
\hline \multicolumn{7}{|c|}{$\begin{array}{l}\text { 2.1.4 Our organization views the development of knowledge and skills in employees as an invest- } \\
\text { ment rather than a cost. }\end{array}$} \\
\hline $\begin{array}{l}\square \text { Strongly } \\
\text { Agree }\end{array}$ & $\square$ Agree & $\begin{array}{l}\square \text { Some- } \\
\text { what Agree }\end{array}$ & $\begin{array}{c}\square \text { Neither } \\
\text { Agree nor } \\
\text { Disagree }\end{array}$ & $\begin{array}{c}\square \text { Some- } \\
\text { what } \\
\text { Disagree }\end{array}$ & $\square$ Disagree & $\square$ Disagree \\
\hline \multicolumn{7}{|c|}{$\begin{array}{l}\text { 2.1.5 Skill and knowledge development of employees happens as an ongoing process in our orga- } \\
\text { nization. }\end{array}$} \\
\hline $\begin{array}{l}\square \text { Strongly } \\
\text { Agree }\end{array}$ & $\square$ Agree & $\begin{array}{l}\square \text { Some- } \\
\text { what Agree }\end{array}$ & $\begin{array}{c}\square \text { Neither } \\
\text { Agree nor } \\
\text { Disagree }\end{array}$ & $\begin{array}{c}\square \text { Some- } \\
\text { what } \\
\text { Disagree }\end{array}$ & $\square$ Disagree & $\square$ Disagree \\
\hline \multicolumn{7}{|c|}{$\begin{array}{l}\text { 2.1.6 Our employer teaches us "why we should do things" and not just "how we should do } \\
\text { things". }\end{array}$} \\
\hline $\begin{array}{l}\square \text { Strongly } \\
\text { Agree }\end{array}$ & $\square$ Agree & $\begin{array}{l}\square \text { Some- } \\
\text { what Agree }\end{array}$ & $\begin{array}{c}\square \text { Neither } \\
\text { Agree nor } \\
\text { Disagree }\end{array}$ & $\begin{array}{c}\square \text { Some- } \\
\text { what } \\
\text { Disagree }\end{array}$ & $\square$ Disagree & $\square$ Disagree \\
\hline $\begin{array}{l}\square \text { Strongly } \\
\text { Agree }\end{array}$ & $\square$ Agree & $\begin{array}{l}\square \text { Some- } \\
\text { what Agree }\end{array}$ & $\begin{array}{c}\square \text { Neither } \\
\text { Agree nor } \\
\text { Disagree }\end{array}$ & $\begin{array}{c}\square \text { Some- } \\
\text { what } \\
\text { Disagree }\end{array}$ & $\square$ Disagree & $\square$ Disagree \\
\hline
\end{tabular}


2.1.8 Our performance measurement and reward systems encourage employees to work together.

\begin{tabular}{c|c|c|c|c|l|l}
$\begin{array}{c}\square \text { Strongly } \\
\text { Agree }\end{array}$ & $\square$ Agree & $\begin{array}{c}\square \text { Some- } \\
\text { what Agree }\end{array}$ & $\begin{array}{c}\square \text { Neither } \\
\text { Agree nor } \\
\text { Disagree }\end{array}$ & $\begin{array}{c}\square \text { Some- } \\
\text { what } \\
\text { Disagree }\end{array}$ & $\square$ Disagree & $\square$ Disagree \\
\hline
\end{tabular}

2.1.9 Our organization measures and rewards employee performance that contributes most to the organization's vision.

\begin{tabular}{|c|c|c|c|c|c|c|}
\hline $\begin{array}{c}\square \text { Strongly } \\
\text { Agree }\end{array}$ & $\square$ Agree & $\begin{array}{c}\square \text { Some- } \\
\text { what Agree }\end{array}$ & $\begin{array}{c}\square \text { Neither } \\
\text { Agree nor } \\
\text { Disagree }\end{array}$ & $\begin{array}{c}\square \text { Some- } \\
\text { what } \\
\text { Disagree }\end{array}$ & $\square$ Disagree \\
$\square$ Disagree \\
\hline
\end{tabular}

2.1.10 Our organization use data they gather from employees to improve our jobs, and to develop the strategy of the organization.

\begin{tabular}{|c|c|c|c|c|l|l|}
\hline $\begin{array}{c}\square \text { Strongly } \\
\text { Agree }\end{array}$ & $\square$ Agree & $\begin{array}{c}\square \text { Some- } \\
\text { what Agree }\end{array}$ & $\begin{array}{c}\square \text { Neither } \\
\text { Agree nor } \\
\text { Disagree }\end{array}$ & $\begin{array}{c}\square \text { Some- } \\
\text { what } \\
\text { Disagree }\end{array}$ & $\square$ Disagree & $\square$ Disagree \\
\hline
\end{tabular}

2.1.11 Our organization communicates to employees the importance of the services roles.

\begin{tabular}{|c|c|c|c|c|l|l|}
$\begin{array}{c}\square \text { Strongly } \\
\text { Agree }\end{array}$ & $\square$ Agree & $\begin{array}{c}\square \text { Some- } \\
\text { what Agree }\end{array}$ & $\begin{array}{c}\square \text { Neither } \\
\text { Agree nor } \\
\text { Disagree }\end{array}$ & $\begin{array}{c}\square \text { Some- } \\
\text { what } \\
\text { Disagree }\end{array}$ & $\square$ Disagree & $\square$ Disagree \\
\hline
\end{tabular}

2.1.12 In our organization, those employees who provide excellent services are rewarded for their efforts.

\begin{tabular}{|c|c|c|c|c|c|c|}
\hline $\begin{array}{c}\square \text { Strongly } \\
\text { Agree }\end{array}$ & $\square$ Agree & $\begin{array}{c}\square \text { Some- } \\
\text { what Agree }\end{array}$ & $\begin{array}{c}\square \text { Neither } \\
\text { Agree nor } \\
\text { Disagree }\end{array}$ & $\begin{array}{c}\square \text { Some- } \\
\text { what } \\
\text { Disagree }\end{array}$ & $\square$ Disagree \\
$\square$ Disagree \\
\hline
\end{tabular}

2.1.13 In this organization, the employees are properly trained to perform their services roles.

\begin{tabular}{|c|c|c|c|c|l|l|}
\hline $\begin{array}{c}\square \text { Strongly } \\
\text { Agree }\end{array}$ & $\square$ Agree & $\begin{array}{c}\square \text { Some- } \\
\text { what Agree }\end{array}$ & $\begin{array}{c}\square \text { Neither } \\
\text { Agree nor } \\
\text { Disagree }\end{array}$ & $\begin{array}{c}\square \text { Some- } \\
\text { what } \\
\text { Disagree }\end{array}$ & $\square$ Disagree & $\square$ Disagree \\
\hline
\end{tabular}

2.1.14 This organization has the flexibility to accommodate the differing needs of employees.

\begin{tabular}{c|c|c|c|c|l|l}
$\begin{array}{c}\square \text { Strongly } \\
\text { Agree }\end{array}$ & $\square$ Agree & $\begin{array}{c}\square \text { Some- } \\
\text { what Agree }\end{array}$ & $\begin{array}{c}\square \text { Neither } \\
\text { Agree nor } \\
\text { Disagree }\end{array}$ & $\begin{array}{c}\square \text { Some- } \\
\text { what } \\
\text { Disagree }\end{array}$ & $\square$ Disagree & $\square$ Disagree \\
\hline
\end{tabular}

2.1.15 Our organization places considerable emphasis in the organization on communicating with employees.

\begin{tabular}{|l|l|c|c|c|l|l|}
\hline $\begin{array}{c}\square \text { Strongly } \\
\text { Agree }\end{array}$ & $\square$ Agree & $\begin{array}{c}\square \text { Some- } \\
\text { what Agree }\end{array}$ & $\begin{array}{c}\square \text { Neither } \\
\text { Agree nor } \\
\text { Disagree }\end{array}$ & $\begin{array}{c}\square \text { Some- } \\
\text { what } \\
\text { Disagree }\end{array}$ & $\square$ Disagree & $\square$ Disagree \\
\hline $3 \quad$ Job Satisfaction \\
\hline $3.1 \quad$ Supervision satisfaction items \\
\hline $3.1 .1 \quad$ My supervisor is quite competent in doing his/her job. \\
\hline
\end{tabular}




\begin{tabular}{|c|c|c|c|c|c|c|}
\hline $\begin{array}{c}\square \text { Strongly } \\
\text { Agree }\end{array}$ & $\square$ Agree & $\begin{array}{c}\square \text { Some- } \\
\text { what Agree }\end{array}$ & $\begin{array}{c}\square \text { Neither } \\
\text { Agree nor } \\
\text { Disagree }\end{array}$ & $\begin{array}{c}\square \text { Some- } \\
\text { what } \\
\text { Disagree }\end{array}$ & $\square$ Disagree & $\square$ Disagree \\
\hline \multicolumn{7}{|c|}{ 3.1.2 My supervisor is unfair to me. } \\
\hline $\begin{array}{c}\square \text { Strongly } \\
\text { Agree }\end{array}$ & $\square$ Agree & $\begin{array}{c}\square \text { Some- } \\
\text { what Agree }\end{array}$ & $\begin{array}{c}\square \text { Neither } \\
\text { Agree nor } \\
\text { Disagree }\end{array}$ & $\begin{array}{c}\square \text { Some- } \\
\text { what } \\
\text { Disagree }\end{array}$ & $\square$ Disagree & $\square$ Disagree \\
\hline \multicolumn{7}{|c|}{ 3.1.3 My supervisor shows too little interest in the feelings of subordinates. } \\
\hline $\begin{array}{c}\square \text { Strongly } \\
\text { Agree }\end{array}$ & $\square$ Agree & $\begin{array}{c}\square \text { Some- } \\
\text { what Agree }\end{array}$ & $\begin{array}{c}\square \text { Neither } \\
\text { Agree nor } \\
\text { Disagree }\end{array}$ & $\begin{array}{c}\square \text { Some- } \\
\text { what } \\
\text { Disagree }\end{array}$ & $\square$ Disagree & $\square$ Disagree \\
\hline \multicolumn{7}{|c|}{ 3.1.4 I like my supervisor. } \\
\hline $\begin{array}{c}\square \text { Strongly } \\
\text { Agree }\end{array}$ & $\square$ Agree & $\begin{array}{c}\square \text { Some- } \\
\text { what Agree }\end{array}$ & $\begin{array}{c}\square \text { Neither } \\
\text { Agree nor } \\
\text { Disagree }\end{array}$ & $\begin{array}{c}\square \text { Some- } \\
\text { what } \\
\text { Disagree }\end{array}$ & $\square$ Disagree & $\square$ Disagree \\
\hline \multicolumn{7}{|c|}{ 3.2 Benefits satisfaction items } \\
\hline $\begin{array}{c}\square \text { Strongly } \\
\text { Agree }\end{array}$ & $\square$ Agree & $\begin{array}{c}\square \text { Some- } \\
\text { what Agree }\end{array}$ & $\begin{array}{c}\square \text { Neither } \\
\text { Agree nor } \\
\text { Disagree }\end{array}$ & $\begin{array}{c}\square \text { Some- } \\
\text { what } \\
\text { Disagree }\end{array}$ & $\square$ Disagree & $\square$ Disagree \\
\hline \multicolumn{7}{|c|}{ 3.2.1 I am satisfied with the benefits I receive. } \\
\hline $\begin{array}{l}\square \text { Strongly } \\
\text { Agree }\end{array}$ & $\square$ Agree & $\begin{array}{c}\square \text { Some- } \\
\text { what Agree }\end{array}$ & $\begin{array}{c}\square \text { Neither } \\
\text { Agree nor } \\
\text { Disagree }\end{array}$ & $\begin{array}{c}\square \text { Some- } \\
\text { what } \\
\text { Disagree }\end{array}$ & $\square$ Disagree & $\square$ Disagree \\
\hline $\begin{array}{c}\text { 3.L.L } \quad \text { he } b \\
\square \text { Strongly } \\
\text { Agree }\end{array}$ & $\square$ Agree & $\begin{array}{c}\square \text { Some- } \\
\text { what Agree }\end{array}$ & $\begin{array}{c}\square \text { Neither } \\
\text { Agree nor } \\
\text { Disagree }\end{array}$ & $\begin{array}{c}\square \text { Some- } \\
\text { what } \\
\text { Disagree }\end{array}$ & $\square$ Disagree & $\square$ Disagree \\
\hline $\begin{array}{c}\text { 3.2.3 } \quad \text { Strongly } \\
\text { Agree }\end{array}$ & $\frac{\text { efit packag }}{\square \text { Agree }}$ & $\begin{array}{l}\text { e have is equ } \\
\square \text { Some- } \\
\text { what Agree }\end{array}$ & $\begin{array}{l}\square \text { Neither } \\
\text { Agree nor } \\
\text { Disagree }\end{array}$ & $\begin{array}{c}\square \text { Some- } \\
\text { what } \\
\text { Disagree }\end{array}$ & $\square$ Disagree & $\square$ Disagree \\
\hline $\begin{array}{c}\text { J.L.4 } \\
\square \text { Strongly } \\
\text { Agree }\end{array}$ & $\frac{\text { e benetits }}{\square \text { Agree }}$ & $\begin{array}{c}\text { do not have v } \\
\square \text { Some- } \\
\text { what Agree }\end{array}$ & $\begin{array}{l}\text { 11ch we shou } \\
\square \text { Neither } \\
\text { Agree nor } \\
\text { Disagree }\end{array}$ & $\begin{array}{l}\text { have. } \\
\square \text { Some- } \\
\text { what } \\
\text { Disagree }\end{array}$ & $\square$ Disagree & $\square$ Disagree \\
\hline \multicolumn{7}{|c|}{$3.3 \quad$ Rewards satisfaction items } \\
\hline $\begin{array}{l}\square \text { Strongly } \\
\text { Agree }\end{array}$ & $\square$ Agree & $\begin{array}{c}\square \text { Some- } \\
\text { what Agree }\end{array}$ & $\begin{array}{c}\square \text { Neither } \\
\text { Agree nor } \\
\text { Disagree }\end{array}$ & $\begin{array}{c}\square \text { Some- } \\
\text { what } \\
\text { Disagree }\end{array}$ & $\square$ Disagree & $\square$ Disagree \\
\hline
\end{tabular}




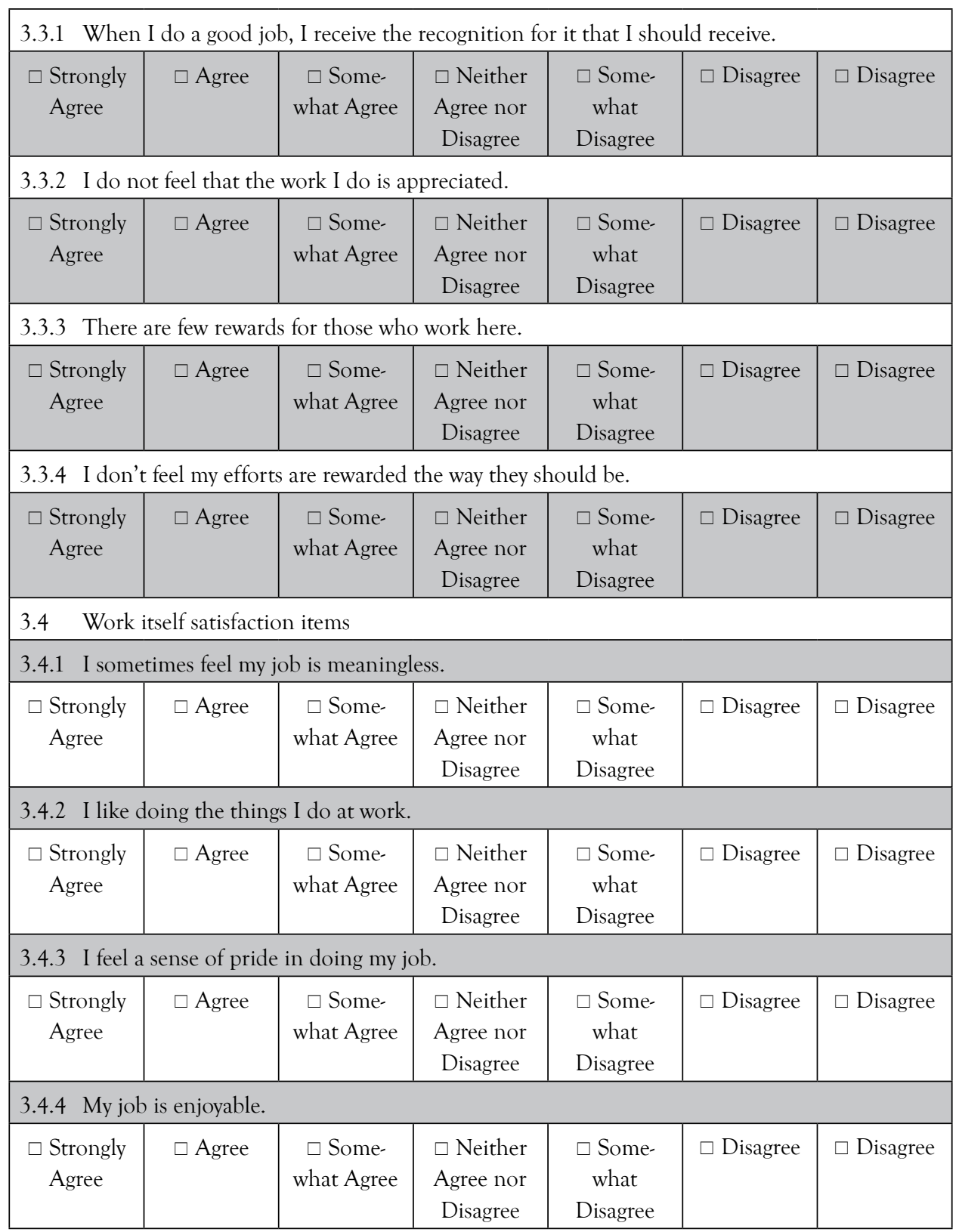


